\title{
Nutrigenic Efficiency Change and Cocoon Crop Loss due to Assimilation of Leaf Spot Diseased Mulberry Leaf in Silkworm, Bombyx Mori L.
}

\author{
Sajad-UI-Haq ${ }^{1^{*}}$, S.S Hasan ${ }^{1}$, Anil Dhar ${ }^{2}$ and Vishal Mittal ${ }^{2}$ \\ ${ }^{1}$ School of Sciences, Indira Gandhi National Open University, New Delhi-1100068 \\ ${ }^{2}$ Central Sericultural Research and Training Institute, Central Silk Board, Pampore,
}

192 121, Jammu and Kashmir, India

"Corresponding author: Sajad-Ul-Haq, School of Sciences, Indira Gandhi National Open University, New Delhi-1100068,Tel: 09596147778; E-mail: sajadulhaqzargar@yahoo.in

Rec date: Feb 12, 2014, Acc date: April 28, 2014, Pub date: May 08, 2014

Copyright: (c) 2014 Sajad, et al. This is an open-access article distributed under the terms of the Creative Commons Attribution License, which permits unrestricted use, distribution, and reproduction in any medium, provided the original author and source are credited.

\begin{abstract}
Healthy growth and development of silkworm largely depending on the quality of mulberry leaves. The activity of sericulture is declining due the reduction of mulberry production area in sericulture practicing countries, which lead to adverse effects on silkworm rearing and cocoon production. Screening for nutritional trait change by feeding leaf spot diseased of mulberry leaf to silkworm, Bombyxmori L. (Lepidoptera: Bombycidae) is an essential prerequisite for better understanding of reduced food consumption, nutritional efficiency loss and low efficiency conversion. The aim of this study was to identify efficiency and cocoon crop loss due to the consumption of leaf spot diseased mulberry leaves to bivoltine silkworm breeds using the hybrid races as $\mathrm{SH} 6$ and $\mathrm{NB}_{4} \mathrm{D}_{2}$. The 1 stday of 5 th stage silkworm larvae of bivoltine strains were subjected to standard gravimetric analysis until spinning for two tothree consecutive generations covering two different seasons on 11 nutrigenic traits. Highly significant $(p \leq 0.01)$ differences were found among all nutrigenic traits of bivoltine silkworm strains in the treated worms compared to the control worms, where healthy leaves were given. Higher nutritional efficiency conversions were found in the bivoltine silkworm strains on efficiency of conversion of ingesta to cocoon and shell than leaf spot diseased leaf fed worms of the same races. Comparatively smaller consumption index, respiration, metabolic rate with superior relative growth rate, and quantum of food ingesta and digesta requisite per gram of cocoon and shell were found; the highest amount was in healthy leaf fed worms than in the diseased leaf fed worms. The significant weight loss in both the races ranged from the $3.38 \%$ to $34.28 \%$ in the diseased leaf fed larva as compared to the healthy leaf fed larva Furthermore, based on the overall loss in nutrigenic traits utilized as index or 'biomarkers', the two bivoltine silkworm strains ( $\mathrm{SH} 6$ and $\mathrm{NB}_{4} \mathrm{D}_{2}$ ) were identified as having the high potential for nutrition efficiency conversion, when healthy leaves were provided to the silkworms. The data from the present study advances our knowledge to study the loss of nutritional efficiency conversion due to the leaf spot disease fed mulberry leaves and their effective commercial consequences in the sericulture industry progress and management.
\end{abstract}

Keywords: Efficiency conversion; Nutrigenic trait; bivoltine breed; leaf spot disease; Bombyxmori $L$.

\section{Introduction}

To achieve the goal of production of good quality silkworm cocoon crop, certain factors play important role. The most important factor is the mulberry leaf, contributing about $38.2 \%$ followed by climate (37.0\%), rearing techniques $(9.3 \%)$, silkworm race $(4.2 \%)$, silkworm egg $(3.1 \%)$ and other factors $(8.2 \%)$ in producing good quality cocoons (1). Hence, quality of mulberry leaf is one of the basic prerequisite of sericulture and plays a pivotal role for successful silkworm cocoon crop. Healthy mulberry leaves influences the growth, development and quality of cocoons formed and thus decide the superiority of silk to a greater extent. Hence production of good quality leaves in terms of nutrition is very important in ensuring quality besides quantity. The mulberry silkworm, Bombyxmori $L$. (Lepidoptera: Bombycidae) is a monophagous insect that feeds exclusively on the mulberry (Morus spp.) foliage for its nutrition and produces the natural proteinaceous silk. Intensive and cautious domestication over centuries has apparently privileged this commercial insect the opportunity to increase in nutrition efficiency.
Nutritional intake has direct impact on the overall genetic traits such as larval and cocoon weight, amount of silk production, pupation, and reproductive traits. The sericulture activity is declining due the reduction of mulberry production area in sericulture practicing countries on silkworm rearing and silk production. This consensus is more pronounced in countries more advanced in sericulture compared to developing countries in Asia and Pacific regions. Thus, among many factors attributed to reduction in silk production, the major one is the loss of nutrition efficiency conversion in Bivoltine silkworm strains in temperate areas because of feeding the worms with the diseased leaves and mostly the leaf spot diseased leaves. This disease is predominant during the rearing period of the silkworms in the temperate region Therefore, one of the key considerations in developing Bivoltine hybrids for temperate regions could be the need for nutrition feeding the bivoltine strains with healthy mulberry leaves. The recent advances in silkworm breeding and those with nutrition efficiency loss have opened up new avenues to evolve different management strategies to control the leaf spot disease, the deadly disease of mulberry. Sericulture in India is practiced to a limited extent in the temperate environment of Jammu and Kashmir. The existing situation provides scope for creating biovoltine hybrids (crossbreeds) as a commercial venture as hybrids above $90 \%$ of total silk production 
(2). Crossbreed nutritional efficiency conversion is low when compared to the existing bivoltine (3). Earlier studies have demonstrated fundamental interaction of nutrition/physiology on gene expression (4). Similarly, nutrition or diet/physiology play important roles in insect gene expression (5), some earlier studies addressed the importance of nutritional aspects, but nutrigenics is often neglected in the selection of silkworm breeds with respect to type of nutrition consumption and efficiency conversion for evaluating the loss due to the foliar diseases on nutritionally efficient silkworm hybrids. However, a clear understanding of the genetic basis and variability in the gene expression of productive and qualitative traits during the analysis of loss of nutrigenetic traits are an important step for the production of good quality leaf and to increase the efficiency conversion.

The purpose of this study is to obtain new data about screening the nutritional efficiency loss in bivoltine silkworms due to leaf spot disease, only to augment current knowledge on gene interaction between nutrition efficiency conversion and loss of quantitative traits due to feeding leaf spot diseased leaves to the bivoltine silkworms under varied conditions.

\section{Materials and Methods}

\section{Bivoltinesilkworm hybrid races}

The two Bivoltine silkworm breeds used for the study were SH6 and $\mathrm{NB}_{4} \mathrm{D}_{2}$. These strains with varied phenotypic quantitative traits, maintained at Silkworm Breeding and Genetics section of Central Sericulture Research and Training Institute, Gallander, Pampore, India, were utilized for the study.

\section{Silkworm rearing}

The disease-free layings (DFLs) from each strain were reared and cocoons were harvested and maintained until eclosion of moths. Healthy female moths emerging on the peak day of eclosion were allowed to mate for 3-4 hours and held until oviposition. The eggs were incubated at $25 \pm 1^{\circ} \mathrm{C}$ temperature and $70-80 \%$ relative humidity (RH) after surface treatment with $2 \%$ formalin solution. 20 to 30 eggs were chosen from each brood and pasted onto to egg sheets. Three such egg sheets for each breed were prepared, wrapped in white tissue paper and boxed with black paper to synchronize the embryonic development. On the day of hatching, the eggs were exposed to light in order to obtain uniform hatching, and finely chopped fresh mulberry leaves were fed to the young eclosions. The whole process from silkworm egg incubation to completion of rearing activities was carried out under hygienic conditions in a silkworm-rearing house that had been thoroughly disinfected with bleach followed by formalin solution. Silkworm rearing was conducted for each breed in plastic trays by feeding them with the healthy and Leaf spot diseased Goshoerami, TR-10, Ichinose and Chinese white variety of mulberry leaves from the well maintained irrigated mulberry plots in rearing room of Entamology and Pathology section of the Institute. A standard rearing procedure was adopted as recommended by Krishnaswami et al. (6). The young larvae (1st-3rd instars) were reared at $26-28{ }^{\circ} \mathrm{C}$ with $80-90 \% \mathrm{RH}$, and late age larvae (4th and 5th instars) were maintained at $24-26^{\circ} \mathrm{C}$ with $70-80 \% \mathrm{RH}$ until the resumption of 4th molt. Each batch was divided into six, one of which was maintained as reserved stock under standard rearing conditions and the other five were subjected to standard gravimetric analysis. Reserve batch of 200 worms of each breed $\left(\mathrm{NB}_{4} \mathrm{D}_{2}\right.$ and $\left.\mathrm{SH} 6\right)$ were fed with the healthy leaves of the selected mulberry varieties in the separate trays in the same rearing room. One batch fed with the healthy leaves and the other three were treated with the 4 th grade leaf spot diseased respective leaves.

\section{Estimation of nutritional traits}

The nutrigenetic traits estimation study was carried out in July 2012 to August 2012 covering the summer rearing period of the temperate area, in a completely randomized block design. Silkworm rearing was conducted following the standard method under the recommended temperature and relative humidity until the 4 th molt. On the 1 st day of fifth instar, 50 healthy silkworm larvae per hybrid in three replications of 150 larvae each were selected for estimation on nutritional traits analysis. Accurately weighed fresh mulberry leaves were fed 3 times a day to the experimental batches and the control. Simultaneously, an additional batch of larvae for each breed was maintained to determine the dry weight on subsequent daily increments in larval weight were recorded separately as suggested by Maynard and Loosli (7). Silkworm rearing continued using appropriate plastic trays. The healthy larvae were counted daily in each replicate, and any missed larvae were replaced from the reserve batch. Left over leaves and excreta were collected on each subsequent day, separated manually and dried in a hot air oven daily at about $100-115^{\circ} \mathrm{C}$ until they reached constant weight using an air-tight electronic balance. When the larvae finished feeding they were shifted to the mountage for spinning at normal ambient temperature of $25 \pm 2{ }^{\circ} \mathrm{C}$ and $\mathrm{RH} \quad 65 \pm 5 \%$. Cocoons were harvested 4-5 days later after completion of cocoon spinning. Harvested cocoons were accessed for quantitative traits using the equations detailed below. The dry weight of left over leaves, excreta, larvae, cocoon, and shell in each of the breed was recorded. The nutrigenetic traits interaction was obtained by utilizing standard gravimetric analysis methods for three consecutive seasons. During the silkworm nutritional study, data were collected on the biomass of larvae and cocoons for the 11 nutrigenetic traits on ingesta, digesta, excreta, reference ratio (RR), relative growth rate (RGR), efficiency conversion of ingesta (ECI) and digesta (ECD) for larva, cocoon, and shell in both the treatments as described by standard gravimetric methods (8-11), the equations with brief description of the nutrigenetic traits evaluated given below.

\section{Ingesta $(\mathrm{g})$}

Total intake of the dry weight (g) of mulberry leaves by silkworm larvae during the 5th stage up to spinning or ripening stage: (Dry weight of leaf fed - Dry weight of left over leaf).

\section{Digesta (g)}

Total assimilated dry food from the intake or ingesta of dry weight of mulberry leaves by silkworm larva during the 5th stage until spinning or ripening: (Dry weight of leaf ingested - dry weight of litter).

\section{Excreta (g)}

Refers to the non-utilized mulberry leaves in the form of litter from the ingested mulberry leaves of a silkworm: (Ingesta - Digesta). 


\section{Reference ratio}

An indirect expression of absorption and assimilation of food. Expresses the ingesta required per unit excreta produced: $(\mathrm{RR}=\mathrm{Dry}$ weight of food ingested / Dry weight of excreta).

\section{Relative growth rate}

Refers to larval gain biomass and indicates the efficiency of conversion of nutrition into larval biomass: $(\mathrm{RGR}=$ Weight gain of the larva during feeding period / 5th stage mean fresh larval weight $(\mathrm{g}) \mathrm{x}$ 5 th stage larval duration in days)

\section{Efficiency conversion of ingesta to larva (\%)}

Associated with the efficiency conversion of ingested nutrition into biomass or body matter at different stages and expressed in percentage. ECI to larva was the efficiency of conversion of ingested food into larva: (ECI larvae = Maximum dry weight of larva / Dry weight of ingesta $\mathrm{x} 100)$.

\section{Efficiency conversion of digesta to larva (\%)}

The expression of efficiency conversion of digesta into larval biomass: $(\mathrm{ECD}$ larvae $=$ Maximum dry weight of larva $/$ Dry weight of digesta $\mathrm{x}$ 100).

\section{Efficiency conversion of ingesta to cocoon (\%)}

This is the most economically important trait used by the sericulture industry. It was the expression of efficiency conversion of ingesta into cocoon, also referred to as the leaf-cocoon conversion rate. This nutrigenetic trait was kept as the ultimate index for assessing the superiority of breed for nutritional efficiency in this investigation: $($ ECI cocoon $=$ Dry weight of cocoon $/$ Dry weight of ingesta $\mathrm{x} 100)$.

\section{Efficiency conversion of digesta to cocoon (\%)}

It was the expression for efficiency conversion of digesta into cocoon: $($ ECD cocoon $=$ Dry weight of cocoon $/$ Dry weight of digesta $\mathrm{x}$ 100).

\section{Efficiency conversion of ingesta to shell (\%)}

This was the expression efficiency conversion of ingesta into shell. It is also referred to as the leaf-shell conversion rate and is the ultimate index to evaluate superiority of breed in nutritional efficiency: (ECI shell $=$ Dry weight of shell $/$ Dry weight of ingesta $\mathrm{x} 100$ ).

\section{Efficiency conversion of digesta to shell (\%)}

The expression of efficiency conversion of digesta into shell: (ECD shell $=$ Dry weight of shell $/$ Dry weight of digesta $\mathrm{x} 100$ ). The data obtained was analyzed using technique of ANOVA as given by Ronald E Walpole to test the effectiveness of leaf spot diseased leaves on the rearing and nutrigenic traits of the treated silkworms.

\section{Results}

Negative correlations were found against all the 11 traits and no positive correlations were found among these traits (Figures 1).

\section{Performance on nutrigenic traits}

Considerable variations were found for 11 nutrigenetic traits and the average larval weight gain (from fourth to fifth instar) among the bivoltine breeds on nutritional parameters and efficiency loss due to feeding the worms with the leaf spot diseased leaves. Data were obtained for ingesta, digesta, excreta, RR, RGR, ECI, and ECD to larval biomass, ECI and ECD to cocoon and shell, I/g and D/g to cocoon and shell for two diseased leaf fed bivoltine breeds under standard nutritional estimation including control breed. There was evidence of clear declines in consumption efficiency in food conversion to biomass for major nutrigenic traits in experimental bivoltine breeds over the control (healthy leaf fed silkworms) worms. (Tables 1-2).

\section{Ingesta, digesta, excreta and reference ratio}

In the experiment, the highest decrease in ingesta $42.6 \%$ was found in $\mathrm{NB}_{4} \mathrm{D}_{2}$ race after feeding the larva with leaf spot infected Chinese white leaves followed by SH6 race when fed with the leaf spot diseased TR-10 leaf. The least decrease was found in SH6 worms fed with diseased Chinese white leaves. The highest decrease of $43 \%, 38.5 \%$ and $37.9 \%$ in digesta was found in SH6 worms fed with the infected leaves of Chinese white, KNG and TR-10 varieties respectively. Decrease in digesta for the $\mathrm{NB}_{4} \mathrm{D}_{2}$ was least compared to SH6. The highest decrease in excreta of more than $50 \%$ was found in $\mathrm{NB}_{4} \mathrm{D}_{2}$ and less than $30 \%$ decrease was found in SH6 when treated with the healthy leaf compared to control. Reference ratio value was the highest in SH6 breed worms fed with $\mathrm{C}$. White and TR-10 Leaf spot infected mulberry leaf followed by the $\mathrm{NB}_{4} \mathrm{D}_{2}$ breed worms.

\begin{tabular}{|c|c|c|c|c|c|c|c|c|c|c|c|c|}
\hline \multirow{2}{*}{$\begin{array}{l}\text { Nutrigenic } \\
\text { traits }\end{array}$} & \multicolumn{3}{|l|}{ GSH } & \multicolumn{3}{|l|}{ KNG } & \multicolumn{3}{|l|}{ C. W } & \multicolumn{3}{|l|}{ TR-10 } \\
\hline & $I^{*}$ & $\mathrm{H}$ & $\% \mathrm{D} /\left(\mathrm{x}^{2}\right)$ & $I^{*}$ & $\mathrm{H}$ & $\% \mathrm{D} /\left(\mathrm{X}^{2}\right)$ & $1^{*}$ & $\mathrm{H}$ & $\% \mathrm{D} /(\mathrm{x} 2)$ & $I^{*}$ & $\mathrm{H}$ & $\% \mathrm{D} /(\mathrm{x} 2)$ \\
\hline $\begin{array}{l}\text { Ingesta/L } \\
(\mathrm{g})\end{array}$ & $2.36\{8.62\}$ & $3.44\{11.0\}$ & $\begin{array}{l}31.5 \\
(0.71)\end{array}$ & $2.16\{8.45\}$ & $3.50\{10.7\}$ & $\begin{array}{l}37.4 \\
(0.38)\end{array}$ & $\begin{array}{l}2.21 \\
\{8.55\}\end{array}$ & $3.85\{11.3\}$ & $\begin{array}{l}42.6 \\
(0.42)\end{array}$ & $\begin{array}{l}2.25 \\
\{8.82\}\end{array}$ & $\begin{array}{l}3.70 \\
\{10.6\}\end{array}$ & $39.2(0.51)$ \\
\hline $\begin{array}{l}\text { Digesta/L } \\
\text { (g) }\end{array}$ & $0.84\{4.89\}$ & $0.9\{5.56\}$ & $\begin{array}{l}8.33 \\
(0.98)\end{array}$ & $0.98\{5.25\}$ & $1.07\{5.49\}$ & $\begin{array}{l}8.06 \\
(0.99)\end{array}$ & $\begin{array}{l}0.73 \\
\{5.65\}\end{array}$ & $0.94\{5.92\}$ & $\begin{array}{l}22.8 \\
(0.97)\end{array}$ & $\begin{array}{l}0.75 \\
\{4.97\}\end{array}$ & $\begin{array}{l}0.87 \\
\{5.36\}\end{array}$ & $13.7(0.99)$ \\
\hline $\begin{array}{l}\text { Excreta/L } \\
\text { (g) }\end{array}$ & $1.55\{7.13\}$ & $2.74\{9.51\}$ & $\begin{array}{l}43.7 \\
(0.53)\end{array}$ & $1.27\{6.4\}$ & $2.80\{9.60\}$ & $\begin{array}{l}54.7 \\
(0.34)\end{array}$ & $\begin{array}{l}1.24 \\
\{6.38\}\end{array}$ & $2.75\{9.55\}$ & $\begin{array}{l}55.1(0.34 \\
\text { ( }\end{array}$ & $\begin{array}{l}1.54 \\
\{7.11\}\end{array}$ & $\begin{array}{l}2.73 \\
\{9.50\}\end{array}$ & $43.7(0.55)$ \\
\hline $\mathrm{RR}(\mathrm{g})$ & $2.30\{8.84\}$ & $2.9\{9.78\}$ & $\begin{array}{l}18.3 \\
(0.93)\end{array}$ & $2.32\{8.70\}$ & $3.30\{10.3\}$ & $\begin{array}{l}29.2 \\
(0.66)\end{array}$ & $\begin{array}{l}1.74 \\
\{8.45\}\end{array}$ & $2.52\{9.96\}$ & $\begin{array}{l}30.8 \\
(0.78)\end{array}$ & $\begin{array}{l}2.16 \\
\{7.58\}\end{array}$ & $3.0\{9.12\}$ & $27.8(0.82)$ \\
\hline
\end{tabular}


Citation: Sajad UH et al (2014) Nutrigenic Efficiency Change and Cocoon Crop Loss due to Assimilation of Leaf Spot Diseased Mulberry Leaf in Silkworm, Bombyx Mori L.. J Plant Pathol Microbiol 5: 220. doi:10.4172/2157-7471.1000220

Page 4 of 7

\begin{tabular}{|c|c|c|c|c|c|c|c|c|c|c|c|c|}
\hline RGR & $0.43\{4.11\}$ & $0.47\{4.65\}$ & $9.86(1.0)$ & $0.52\{3.86\}$ & $0.66\{5.52\}$ & $\begin{array}{l}21.7 \\
(0.99)\end{array}$ & $\begin{array}{l}0.46 \\
\{3.73\}\end{array}$ & $0.90\{3.93\}$ & $\begin{array}{l}50.9 \\
(0.81)\end{array}$ & $\begin{array}{l}0.74 \\
\{4.93\}\end{array}$ & $\begin{array}{l}0.97 \\
\{5.64\}\end{array}$ & $23.4(0.97)$ \\
\hline ECIL (\%) & $53.6\{42.4\}$ & $56.3\{43.9\}$ & $4.86(0.9)$ & $59.5\{40.1\}$ & $61.0\{41.9\}$ & $\begin{array}{l}2.30 \\
(0.82)\end{array}$ & $\begin{array}{l}45.7 \\
\{38.9\}\end{array}$ & $55.4\{43.0\}$ & $\begin{array}{l}17.5 \\
(0.08)\end{array}$ & $\begin{array}{l}49.5 \\
\{41.6\}\end{array}$ & $\begin{array}{l}53.4 \\
\{45.8\}\end{array}$ & $7.20(0.77)$ \\
\hline ECDL (\%) & $18.6\{21.4\}$ & $20.2\{22.4\}$ & $\begin{array}{l}7.82 \\
(0.72)\end{array}$ & $17.7\{21.6\}$ & $23.0\{23.1\}$ & $\begin{array}{l}23.8 \\
(0.15)\end{array}$ & $\begin{array}{l}19.6 \\
\{20.7\}\end{array}$ & $25.4\{23.1\}$ & $\begin{array}{l}22.8 \\
(0.05)\end{array}$ & $\begin{array}{l}22.9 \\
\{19.6\}\end{array}$ & $\begin{array}{l}25.5 \\
\{21.4\}\end{array}$ & $10.0(0)$ \\
\hline ECIC (\%) & $45.5\{47.0\}$ & $48.3\{48.6\}$ & $5.64(0.8)$ & $41.6\{50.5\}$ & $45.0\{51.3\}$ & $\begin{array}{l}7.15 \\
(0.82)\end{array}$ & $\begin{array}{l}39.5 \\
\{44.7\}\end{array}$ & $46.6\{46.9\}$ & $\begin{array}{l}15.2 \\
(0.23)\end{array}$ & $\begin{array}{l}44.3 \\
\{42.5\}\end{array}$ & $\begin{array}{l}51.5 \\
\{40.0\}\end{array}$ & $14.0(0.19)$ \\
\hline ECDC (\%) & $13.3\{25.5\}$ & $14.6\{6.7\}$ & $\begin{array}{l}8.33 \\
(0.94)\end{array}$ & $13.6\{24.8\}$ & $15.0\{28.8\}$ & $\begin{array}{l}12.4 \\
(0.62)\end{array}$ & $\begin{array}{l}12.5 \\
\{26.2\}\end{array}$ & $15.5\{30.1\}$ & $\begin{array}{l}19.1 \\
(0.52)\end{array}$ & $\begin{array}{l}11.4 \\
\{28.6\}\end{array}$ & $\begin{array}{l}13.4 \\
\{30.3\}\end{array}$ & $15.3(0.73)$ \\
\hline ECIS (\%) & $16.4\{23.8\}$ & $17.7\{24.8\}$ & $\begin{array}{l}7.66 \\
(0.74)\end{array}$ & $20.3\{26.7\}$ & $21.0\{27.6\}$ & $\begin{array}{l}5.61 \\
(1.0)\end{array}$ & $\begin{array}{l}16.5 \\
\{23.9\}\end{array}$ & $18.2\{25.2\}$ & $9.35(0.9)$ & $\begin{array}{l}20.4 \\
\{26.8\}\end{array}$ & $\begin{array}{l}21.5 \\
\{27.6\}\end{array}$ & $5.37(0.90$ \\
\hline ECDS (\%) & $7.66\{14.6\}$ & $8.46\{15.9\}$ & $\begin{array}{l}9.53 \\
(0.69)\end{array}$ & $7.54\{15.9\}$ & $8.30\{16.7\}$ & $\begin{array}{l}9.62 \\
(0.8)\end{array}$ & $\begin{array}{l}6.44 \\
\{16.0\}\end{array}$ & $7.56\{16.8\}$ & $\begin{array}{l}14.8 \\
(0.76)\end{array}$ & $\begin{array}{l}8.54 \\
\{16.9\}\end{array}$ & $\begin{array}{l}9.46 \\
\{17.9\}\end{array}$ & $9.76(0.85)$ \\
\hline $\begin{array}{l}\text { SEm } \pm / F- \\
\text { test }\end{array}$ & 0.43 & 0.68 & ** & 0.52 & 0.58 & ** & 0.49 & 0.70 & ** & 0.35 & 0.44 & ** \\
\hline $\mathrm{CD}$ at $5 \%$ & 1.26 & 2.0 & & 1.52 & 1.71 & & 1.46 & 2.05 & & 1.04 & 1.29 & \\
\hline CV (\%) & 3.94 & 5.83 & & 4.66 & 4.80 & & 4.66 & 5.91 & & 3.22 & 3.64 & \\
\hline $\mathrm{SD} \pm$ & 17.94 & 18.72 & & 18.67 & 19.22 & & 16.19 & 18.01 & & 16.40 & 19.23 & \\
\hline
\end{tabular}

Table 1: Effect of leaf spot diseased mulberry leaf on various nutrigenic parameters of $\mathrm{NB}_{4} \mathrm{D}_{2}$ race of silkworm Bombyxmori L. in the fifth instar. $\mathrm{H}=$ healthy, $\mathrm{I}=$ Infected, $\% \mathrm{D}=$ Percent Decrease, Values in smallBrackets () are the $\chi 2$-test values, values in long Brackets \{\} are arc sinevaluesD/L, digesta per larva; I/L, ingestaperLarva; ECD, efficiency conversion of digesta; ECI, efficiency of conversion of ingesta; RR, reference ratio; RGR, relative growth rate;

\begin{tabular}{|c|c|c|c|c|c|c|c|c|c|c|c|c|}
\hline \multirow{2}{*}{$\begin{array}{l}\text { Nutrigenic } \\
\text { traits }\end{array}$} & \multicolumn{3}{|l|}{ GSH } & \multicolumn{3}{|l|}{ KNG } & \multicolumn{3}{|l|}{ CW } & \multicolumn{3}{|l|}{ TR-10 } \\
\hline & $1^{*}$ & $\mathrm{H}$ & $\% \mathrm{D} /\left(\mathrm{x}^{2}\right)$ & $\mathrm{I}^{*}$ & $\mathrm{H}$ & $\% \mathrm{D} /\left(\mathrm{x}^{2}\right)$ & $1^{*}$ & $\mathrm{H}$ & $\% \mathrm{D} /\left(\mathrm{x}^{2}\right)$ & $1^{*}$ & $\mathrm{H}$ & $\% \mathrm{D} /\left(\mathrm{x}^{2}\right)$ \\
\hline Ingesta/L(g) & $\begin{array}{l}2.29 \\
\{8.70\}\end{array}$ & $\begin{array}{l}3.52 \\
\{10.8\}\end{array}$ & $34.8(0.64)$ & $\begin{array}{l}2.46 \\
\{9.01\}\end{array}$ & $3.46\{10.7\}$ & $29.1(0.76)$ & $\begin{array}{l}2.24 \\
\{11.9\}\end{array}$ & $4.31\{8.59\}$ & $\begin{array}{l}48.1 \\
(0.07)\end{array}$ & $3.44\{11.1\}$ & $3.74\{10.6\}$ & $8.83(0.96)$ \\
\hline Digesta/L(g) & $\begin{array}{l}0.76 \\
\{4.99\}\end{array}$ & $\begin{array}{l}0.86 \\
\{5.32\}\end{array}$ & $11.7(1.0)$ & $\begin{array}{l}0.73 \\
\{4.88\}\end{array}$ & $1.28\{6.41\}$ & $43.0(0.77)$ & $\begin{array}{l}0.53 \\
\{5.75\}\end{array}$ & $1.01\{4.17\}$ & $\begin{array}{l}47.5 \\
(0.05)\end{array}$ & $0.63\{5.32\}$ & $0.86\{4.53\}$ & $37.5(0.95)$ \\
\hline Excreta/L(g) & $\begin{array}{l}1.59 \\
\{7.25\}\end{array}$ & $\begin{array}{l}2.68 \\
\{9.41\}\end{array}$ & $40.5(0.62)$ & \begin{tabular}{|l|}
1.76 \\
$\{7.62\}$
\end{tabular} & $2.55\{9.18\}$ & $31.0(0.80)$ & $\begin{array}{l}1.67 \\
\{10.9\}\end{array}$ & $3.58\{7.42\}$ & $\begin{array}{l}53.4 \\
(0.05)\end{array}$ & $2.79\{9.58\}$ & $2.78\{10.9\}$ & $0.43(1.0)$ \\
\hline $\mathrm{RR}(\mathrm{g})$ & $\begin{array}{l}2.31 \\
\{8.73\}\end{array}$ & $\begin{array}{l}2.84 \\
\{9.69\}\end{array}$ & $18.7(0.94)$ & $\begin{array}{l}2.43 \\
\{8.96\}\end{array}$ & $3.20\{10.2\}$ & $23.9(0.85)$ & $\begin{array}{l}1.98 \\
\{11.3\}\end{array}$ & $3.90\{8.09\}$ & $\begin{array}{l}49.1 \\
(0.08)\end{array}$ & $2.32\{0.72\}$ & $3.46\{11.3\}$ & $49.3(0.51)$ \\
\hline RGR & $\begin{array}{l}13.9 \\
\{3.95\}\end{array}$ & $\begin{array}{l}15.1 \\
\{4.30\}\end{array}$ & $8.01(1.0)$ & $\begin{array}{l}14.6 \\
\{3.89\}\end{array}$ & $16.3\{4.26\}$ & $10.7(1.0)$ & $\begin{array}{l}12.5 \\
\{4.37\}\end{array}$ & $15.4\{3.84\}$ & $\begin{array}{l}18.9 \\
(0.98)\end{array}$ & $13.0\{4.30\}$ & $14.3\{4.37\}$ & $9.85(1.0)$ \\
\hline ECIL (\%) & $\begin{array}{l}0.48 \\
\{21.8\}\end{array}$ & $\begin{array}{l}0.56 \\
\{22.8\}\end{array}$ & $15.4(0.94)$ & \begin{tabular}{|l|}
0.46 \\
$\{22.4\}$
\end{tabular} & $0.56\{23.8\}$ & $16.8(0.86)$ & $\begin{array}{l}0.45 \\
\{23.3\}\end{array}$ & $0.58\{20.7\}$ & $\begin{array}{l}22.9 \\
(0.45)\end{array}$ & $0.45\{22.2\}$ & $0.57\{23.1\}$ & $25.9(0.86)$ \\
\hline ECDL (\%) & $\begin{array}{l}16.7 \\
\{40.6\}\end{array}$ & $\begin{array}{l}18.5 \\
\{43.0\}\end{array}$ & $9.91(0.68)$ & \begin{tabular}{|l|}
18.4 \\
$\{40.5\}$
\end{tabular} & $20.5\{41.8\}$ & $10.4(0.86)$ & $\begin{array}{l}20.4 \\
\{43.8\}\end{array}$ & $23.4\{40.1\}$ & $\begin{array}{l}12.8 \\
(0.26)\end{array}$ & $18.5\{44.6\}$ & $21.8\{43.8\}$ & $17.8(0.04)$ \\
\hline ECIC (\%) & $\begin{array}{l}42.5 \\
\{24.0\}\end{array}$ & $\begin{array}{l}46.5 \\
\{25.4\}\end{array}$ & $8.76(0.87)$ & \begin{tabular}{|l|}
42.3 \\
$\{25.3\}$
\end{tabular} & $44.5\{26.9\}$ & $5.03(0.70)$ & $\begin{array}{l}41.6 \\
\{28.9\}\end{array}$ & $47.9\{26.8\}$ & $\begin{array}{l}13.2 \\
(0.63)\end{array}$ & $40.4\{27.8\}$ & $49.3\{28.9\}$ & $22.2(0.39)$ \\
\hline ECDC (\%) & $\begin{array}{l}52.3 \\
\{46.2\}\end{array}$ & $\begin{array}{l}54.6 \\
\{47.6\}\end{array}$ & $4.27(0.88)$ & \begin{tabular}{|l|}
53.2 \\
$\{46.8\}$
\end{tabular} & $58.3\{49.7\}$ & $8.73(0.61)$ & $\begin{array}{l}48.5 \\
\{46.9\}\end{array}$ & $53.3\{44.1\}$ & $\begin{array}{l}9.05 \\
(0.59)\end{array}$ & $50.3\{48.0\}$ & $55.3\{46.9\}$ & $9.90(0.44)$ \\
\hline ECIS (\%) & $\begin{array}{l}16.6 \\
\{16.2\}\end{array}$ & $\begin{array}{l}17.3 \\
\{16.8\}\end{array}$ & $3.77(0.94)$ & $\begin{array}{l}20.2 \\
\{15.6\}\end{array}$ & $22.6\{16.5\}$ & $10.7(0.93)$ & $\begin{array}{l}17.8 \\
\{15.5\}\end{array}$ & $20.1\{17.0\}$ & $\begin{array}{l}11.4 \\
(0.71)\end{array}$ & $15.2\{18.0\}$ & $21.4\{15.5\}$ & $41.1(0.24)$ \\
\hline
\end{tabular}


Page 5 of 7

\begin{tabular}{|l|l|l|l|l|l|l|l|l|l|l|l|l|}
\hline ECDS (\%) & $\begin{array}{l}7.87 \\
\{24.0\}\end{array}$ & $\begin{array}{l}8.39 \\
\{24.5\}\end{array}$ & $6.24(0.98)$ & $\begin{array}{l}7.28 \\
\{26.6\}\end{array}$ & $8.13\{28.3\}$ & $10.5(0.48)$ & $\begin{array}{l}7.24 \\
\{24.9\}\end{array}$ & $8.57\{26.6\}$ & $\begin{array}{l}15.5 \\
(0.78)\end{array}$ & $6.99\{27.5\}$ & $9.56\{24.9\}$ & $36.7(0.01)$ \\
\hline SEm $\pm / f-t e s t$ & 0.27 & 0.28 & $* *$ & 0.34 & 0.33 & $* *$ & 0.29 & 0.20 & $* *$ & 0.30 & 0.33 \\
\hline CD at $5 \%$ & 0.79 & 0.80 & & 1.00 & 0.96 & & 0.84 & 0.57 & & 0.88 & 0.95 \\
\hline CV $(\%)$ & 2.91 & 2.81 & & 3.61 & 3.24 & & 2.83 & 2.12 & & 2.94 & 3.52 \\
\hline SD \pm & 17.03 & 17.95 & & 17.29 & 18.52 & & 17.56 & 16.76 & & 18.59 & 16.23 & \\
\hline
\end{tabular}

Table 2: Effect of leaf spot diseased mulberry leaf on various nutrigenic parameters of SH6 race of silkworm Bombyxmori L. in the fifth instar. $\% \mathrm{D}=$ Percent Decrease, $\mathrm{H}=$ healthy, $\mathrm{I}=$ Infected, Values in short Brackets () are the $\chi 2$-test values, values in long Brackets \{\} are arc sine values D/L, digesta per larva; I/L, ingesta per Larva; ECD, efficiency conversion of digesta; ECI, efficiency of conversion of ingesta; RR, reference ratio; RGR, relative growth rate.

\begin{tabular}{|c|c|c|c|c|c|c|c|c|c|c|c|c|c|}
\hline \multirow{3}{*}{$\begin{array}{l}\text { Silkwom } \\
\text { Race }\end{array}$} & \multirow[t]{3}{*}{ Parameters } & \multicolumn{12}{|c|}{ Variety } \\
\hline & & \multicolumn{3}{|l|}{ GSH } & \multicolumn{3}{|l|}{ KNG } & \multicolumn{3}{|l|}{$C W$} & \multicolumn{3}{|c|}{ TR-10 } \\
\hline & & $\mathrm{H}$ & $I^{*}$ & $\%$ Loss & $\mathrm{H}$ & $I^{*}$ & $\%$ Loss & $\mathrm{H}$ & $I^{*}$ & $\%$ Loss & $\mathrm{H}$ & $I^{*}$ & $\%$ Loss \\
\hline \multirow[t]{2}{*}{ NBD } & $\begin{array}{l}\text { Average wt. in4th } \\
\text { Instar }\end{array}$ & 5.05 & 4.22 & $\begin{array}{l}3.38 \\
(0.83)\end{array}$ & 5.94 & 5.34 & $\begin{array}{l}10.2 \\
(0.97)\end{array}$ & 6.93 & 4.55 & $34.28(0.35)$ & 7.72 & 6.31 & $18.3(0.73)$ \\
\hline & $\begin{array}{l}\text { Average larval wt. in } \\
5 \text { th instar }\end{array}$ & 11.6 & 10.4 & $\begin{array}{l}9.28 \\
(0.91)\end{array}$ & 14.06 & 12 & $\begin{array}{l}14.7 \\
(0.75)\end{array}$ & 12.6 & 10.74 & $14.65(0.78)$ & 13.3 & 11.1 & $17.1(0.61)$ \\
\hline \multirow[t]{2}{*}{$\mathrm{SH} 6$} & $\begin{array}{l}\text { Average wt. in4th } \\
\text { Instar }\end{array}$ & 5.59 & 4.78 & $\begin{array}{l}3.97 \\
(0.90)\end{array}$ & 5.36 & 4.73 & $\begin{array}{l}11.8 \\
(0.95)\end{array}$ & 6.83 & 4.86 & $28.88(0.5)$ & 5.36 & 4.52 & $15.6(0.3)$ \\
\hline & $\begin{array}{l}\text { Average larval wt. in } \\
5 \text { th instar }\end{array}$ & 12.9 & 11.2 & $\begin{array}{l}13.5 \\
(0.81)\end{array}$ & 13.02 & 11.2 & $\begin{array}{l}14.1 \\
(0.77)\end{array}$ & 113 & 93.52 & $17.48(0.03)$ & 134 & 108 & $6.17(0)$ \\
\hline \multicolumn{2}{|c|}{ CV (\%)/f-test } & 1.60 & 4.34 & $* *$ & 2.86 & 3.61 & $* *$ & 2.95 & 8.90 & ** & 1.72 & 8.09 & $* *$ \\
\hline \multicolumn{2}{|l|}{ Cd at $5 \%$} & 1.19 & 2.96 & & 2.37 & 2.65 & & 2.65 & 6.57 & & 0.57 & 6.70 & \\
\hline
\end{tabular}

Table 3: Larval weight of $\mathrm{NB}_{4} \mathrm{D}_{2}$ and SH6 silkworm breed in 4th and 5th instars. Values in Brackets are the $\chi^{2}$-test value.

\section{Relative growth rate}

The highest relative growth rate of more than $50 \%$ was found in $\mathrm{NB}_{4} \mathrm{D}_{2}$ race when fed with the diseased Chinese white leaf, followed by $\mathrm{NB}_{4} \mathrm{D}_{2}$ when fed with 4 th grade leaf spot diseased Goshoerami leaf.

\section{Efficiency of conversion of ingesta and digesta to larval biomass}

The efficiency of mulberry leaf ingested and digested in conversion to silkworm larval biomass or body varied prominently among the bivoltine breeds (Table 1 and 2) when fed with leaf spot infected mulberry leaf. The highest decrease of $17.5 \%$ efficiency conversion of ingesta was found in $\mathrm{NB}_{4} \mathrm{D}_{2}$ when fed with leaf spot diseased $\mathrm{C}$. White leaf and $23.8 \%$ decrease in efficiency conversion of digesta for larva was recorded in $\mathrm{NB}_{4} \mathrm{D}_{2}$ fed with Leaf spot diseased $\mathrm{KNG}$ leaf.

\section{Efficiency of conversion of ingesta and digesta to cocoon and shell}

The significant decrease of $19.1 \%$ in efficiency conversion to cocoon was shown in $\mathrm{NB}_{4} \mathrm{D}_{2}$ race when fed with $\mathrm{C}$. white Leaf spot diseased leaf followed by more than $15 \%$ decrease in TR-10 fed diseased leaf in $\mathrm{NB}_{4} \mathrm{D}_{2}$ and $\mathrm{SH} 6$. The $14.6 \%$ significant decrease in efficiency conversion of digesta to cocoon was seen in SH6 when C. white leaf was fed and 3.77\% least significant in $\mathrm{NB}_{4} \mathrm{D}_{2}$, when fed with diseased Goshoerami leaf. The significant decrease in efficiency conversion of ingesta to shell ranged from $14.8 \%$ in $\mathrm{NB}_{4} \mathrm{D}_{2}$ to $3.36 \%$ in $\mathrm{SH} 6$ when both fed with the leaf spot diseased Goshoerami leaf. In the fourth instar the significant larval weight loss of $41.3 \%$ due to leaf spot disease was found in $\mathrm{NB}_{4} \mathrm{D}_{2}$ when fed with diseased mulberry and $56.7 \%$ weight loss in fifth instar. The least decrease was found in fifth instar when the worms become the voracious feeders followed by $36.4 \%$ and $33.1 \%$ in SH6 race when fed with leaf spot infected Chinese white and Goshoerami leaves The least decrease of $3.70 \%$ in larval weight loss was found in $\mathrm{NB}_{4} \mathrm{D}_{2}$ when fed with Goshoerami Leaf Spot diseased leaves.

Based on all morphological, nutrigenic traits and lower consumption of mulberry leaves and maximum efficiency of conversion of nutrients, with highly significant $(\mathrm{p} \leq 0.001)$ differences in bivoltine breeds for 11 nutrigenetic traits, two bivoltine silkworm breeds, $\mathrm{NB}_{4} \mathrm{D}_{2}$ and $\mathrm{SH} 6$ were identified as potential nutritionally efficient breeding resources for comparative studies in effect of diseased and healthy leaves on larval, cocoon and shell parameters. Silkworm breeding can be defined as the science of improving the genetic entity of silkworms in relation to their economic utility. Silk producing countries in Asia and Pacific regions experience serious problems in the field of silkworm rearing on healthy leaf. This investigation intends to serve as a guideline to organize or revive 
healthy silkworm feeding programs, as well as a quick reference to sericulture loss. It also offers a brief background on the change in silkworm nutrition and physiology. It also outlines the necessary facilities and tools required to establish modern silkworm breeding programs for the sustenance of sericulture in the temperate regions. The study of the interactions between nutrition and quantitative traits, the major physiological and biochemical traits of silkworm showed a greater decline in consumption with decrease of food efficiency conversion into biomass in experimental bivoltine breeds compared to the healthy leaf fed silkworms of the same breed. A similar result was reported for polyvoltine and commercial hybrid silkworms by Maribashetty et al. (12) and Meneguim et al. (13) respectively. Such dietary factors and related metabolic interactions on specific gene expression were also reported by Walker and Blackburn. Nutrition affects nearly all biological processes including the rates of biochemical and physiological reactions $(14,15)$, and eventually can affect the larval quality or quantity of cocoon crops in the silkworm. Several reports (15-18) demonstrated that silkworms were more responsive to nutrition supplement during the 4th and 5th stages, which are recommended for the recognition and selection of nutritional efficient changes due to leaf spot disease. Hence, the nutrition utilization study was confined to the 5th instar larvae, since $80-85 \%$ of total leaf consumption was observed in this stage of silkworm development $(16,18)$ and the silk gland stimulation starts at this stage. For instance, bivoltine breeds reared in temperate countries are known to be less nutritionally efficient, which is also true with cross breeds that have evolved for a tropical climate $(3,19-20)$. It is essential to analyze nutrigenetic traits reduction to understand the racial difference among bivoltinegermplasm breeds for commercial purposes. Recently, the effects of nutrigenetic traits for bivoltine germplasm breeds also have been shown by Ramesha et al. (3). The success of the sericulture industry depends upon several factors, including production of quality mulberry leaves. This factor is of vital importance, since it accounts for $60 \%$ of total expenditures (21). It is well understood that the majority of the economically important genetic traits of silkworm are qualitative in nature, and phenotypic expression is greatly influenced by the environmental and leaf factors such as temperature, relative humidity, light, diseased leaf and nutrition $(3,6,22-23)$. Therefore, it is essential to gauge the degree of phenotypic difference of the economical traits to understand the genetic steadiness under the controlled nutrition conditions. The problem of balancing and fixing the desirable traits for a given environment is a challenging task for the silkworm breeder. Hence, understanding the range of a reaction of the selected breeds to variable nutritional conditions especially to feeding with diseased leaf, is important for the breeder to utilize them appropriately in hybrid programs. In order to achieve greater success in this regard, it is important to understand the level of nutrition efficiency in bivoltine silkworm breeds and to analyze the least significant loss to cocoon crop because of leaf spot disease. The main objective of this study was to identify the conversion index and efficiency of conversion of ingesta, when larva were fed with the leaf spot diseased mulberry leaves, to biomass through standard gravimetric method for three successive generations on different races and varieties of mulberry, is supported by earlier observations (24-27). Our emphasis was on the phenotypic manifestation of 11 nutrigenetic traits. The results revealed highly significant $(p \leq 0.001)$ variability among the two bivoltine breeds with respect to 11 nutrigenic traits over, when the larvae were fed ith the leaf spot diseased mulberry leaf. Although earlier studies showed that somebivoltine breeds are moderately nutritionally efficient (12,28-29), We concluded that bivoltine breeds with minimum consumption index and maximum efficiency of conversion of ingesta/cocoon identified strains $\mathrm{NB}_{4} \mathrm{D}_{2}$ and SH6 as potential bivoltine breeding resource material for the development of nutritionally efficient breeds/hybrids in Asia especially Indian subcontinent, pacific regions and other temperate regions(30-36).

\section{Acknowledgement}

Authors are highly thankful to Dr. K. A Sahaf, Director CSR\&TI, Govt. of India, Pampore, Kashmir, Indiafor providing all the necessary facilities and encouragement for the present work. We duly acknowledge the contributions of Prof. Vijayshri, Director, School of Sciences, IGNOU, Main Campus, New Delhi and Dr. IrfanIllahi, Scientist-B CSR\&TI, Pampore and Prof. NeeraKapoor, (Coordinator School of Sciences, IGNOU), Prof. Amrita Nigam and Prof. JaswantSokhi eminent professors of the School of Sciences, IGNOU, Main Campus, MaidanGarhi, New Delhi for their generous and enthusiastic help and constructive suggestions.

\section{References}

1. Hamano K, Miyazawa K, Mukiyama F (1986)Racial difference in the feeding habit of the silkworm, Bombyxmori. Journal of Sericultural Science of Japan 55: 68-72.

2. Ramesha C, Seshagiri SV, Rao CGP (2009) Evaluation and identification of superior polyvoltine crossbreeds of mulberry silkworm, Bombyxmori L. Journal of Entomology 6: 179-188.

3. Ramesha C, Anuradha CM, Lakshmi H,SugnanaKumari S, Seshagiri SV et al. (2010)Nutrigenetic traits analysis for identification of nutritionally efficient silkworm germplasm breeds. Biotechnology 9: 131-140.

4. Phillips CN, Tierney AC, Roche, HM (2008) Gene-nutrient interactions in the metabolic syndrome. Journal of Nutrigenetics and Nutrigenomics 1: $136-151$.

5. Rharrabe K, Sayah F, La Font R(2010) Dietary effects of four phytoecdysteroids on growth and development of the Indian meal moth, Plodiainterpunctella. Journal of Insect Science 10:13

6. Krishnaswami S, Narasimhanna MN, Surayanarayana SK, Kumararaj S (1973) Manual on sericulture 2: Silkworm rearing. UN Food and Agriculture Organization: 54-88

7. Maynard AL, Loosli KJ (1962) Animal Nutrition, 5th Edition. McGraw Hill.

8. Waldbauer GP (1968) The consumption and utilization rate of food by insects. Advanced Insect Physiology 5: 229-288.

9. Scriber JM, Feeny $\mathrm{P}(1979)$ Growth of herbivorous caterpillars in relation to feeding specialization and to the growth form of their food plant. Ecology 60: 829-850.

10. Kogan M, Parra JRP (1981) Techniques and applications of measurements of consumption and utilization of feed by phytophagous insects. In: Bhaskaran G, Friedman S, Rodrigues JG, Editors. Current Topics in Insect Endocrinology and Nutrition. Plenum Press: 337-352.

11. Slansky F, Scriber JM (1985) Food consumption and utilization. In: Kerkut AA, Gilbert LI, Editors. Comprehensive Insect Physiology, Biochemistry and Pharmacology. Pergamon Press: 87-163.

12. Maribashetty VG, Aftab Ahmed CA, Chandrakala MV, Rajanna GS (1999) Consumption and conversion efficiency of food and water in new multivoltine breeds of silkworm, Bombyxmori L. Indian Journal of Sericulture 38: 140-144.

13. Meneguim AM, Lustri C, Oliveira DD, Yada IFU, Pasini A(2010)Bromatological characterization of mulberry cultivars, Morus spp., and determination of nutritional indexes of Bombyxmori L. (Lepidoptera: Bombycidae). Neotropical Entomology 39: 506-512.

14. Parra JRP, Kogan M (1981) Comparative analysis of methods for measurements of food intake and utilization using the soybean looper, 
Citation: Sajad UH et al (2014) Nutrigenic Efficiency Change and Cocoon Crop Loss due to Assimilation of Leaf Spot Diseased Mulberry Leaf in Silkworm, Bombyx Mori L.. J Plant Pathol Microbiol 5: 220. doi:10.4172/2157-7471.1000220

Page 7 of 7

Pseudoplusiaincludens and artificial media. Entomological Experimental Application 30: 45-57.

15. Paul DC, SubbaRao G, Deb DC(1992) Impact of dietary moisture on nutritional indices and growth of Bombyxmori and concomitant larval duration. Journal of Insect Physiology 38: 229-235.

16. Ueda $S(1965)$ Changes in some quantitative factors and their mutual relationships concerning the growth and development in the fifth larval instar of the silkworm, Bombyxmori L. Bulletin of Sericultural Experiment Station in Japan 19: 331-341.

17. Mano Y, Asaoka K, Ihara O, Nakagawa H, HirabayashiTet al. (1991) Breeding and evaluation of adaptability of silkworm, Bombyxmori to new low cost artificial diet, LPY lacking mulberry leaf powder. Bulletin of National Industrial Sericultural Entomological Science 3: 31-56.

18. Rahmathulla VK, HaqueRufaie SZ, Himanthraj MT, Vindhya GS, Rajan RK (2005) Food ingestion, assimilation and conversion efficiency of mulberry silkworm, Bombyxmori L. International Journal of Industrial Entomology 11: 1-12.

19. Rahmathulla VK, Vindya GS, Sreenivasa G, Geethadevi RG (2003) Evaluation of the consumption and nutritional efficiency in three new bivoltine hybrids (CSR series) silkworm Bombyxmori L. Journal of Experimental Zoology 6: 157-161.

20. Ramesha C, Raju PJ (2009b) Analysis of nutrigenetic traits for identification of nutritionally efficient germplasm breeds of bivoltine silkworm, Bombyxmori L. National Conference on Recent Trends in Animal Physiology: 27

21. Datta RK, Nanavaty M (2005) Global silk industry: A complete source book. Universal Publishers.

22. Thaigarajan, Bhargava VSK, Ramesh Babu M, Nagaraju B(1993) Differences in seasonal performance of 26 strains of silkworm Bombyxmori (Bombycidae). Journal of the Lepidopterists' Society 47 : 321-337.

23. Zhang YH, Xu AY, Wei YD, Li MW, Hou CX, et al. (2002) Studies on feeding habits of silkworm germplasm resources for artificial diet without mulberry. ActaSericologicaSinica 28: 333-336.

24. Hassanein MH, El Shaaraway MF, El Garthy AT (1972) Food assimilation and out put of the silk in the different races of the silkworm, Bombyxmori L. Bulletin of the Entomological Society of Egypt 56: 333-337.
25. Anantharaman KV, Magadum SB, Datta RK (1994) Feed efficiency of silkworm, Bombyxmori L. hybrid $\left(\mathrm{NB}_{4} \mathrm{D}_{2} \mathrm{x}\right.$ KA). Insect Science Application 15: 111-116.

26. Trivedy K, Nair KS (1999) Feed conversion efficiency of improved multi $\mathrm{x}$ biovoltine hybrids of silkworm, Bombyxmori L. Indian Journal of Sericulture 38: 30-34.

27. Kumaresan P, Sinha RK, Sahni NK, Sekar S(2000) Genetic variability and selection indices for economic quantitative traits of multivoltine mulberry silkworm, Bombyxmori L. genotypes. Sericologia 40: 595-605.

28. Remadevi OK, Magadum SB, Shivashankar N, Benchamin KV (1992) Evaluation of the food utilization efficiency in some polyvoltine breeds of silkworm, Bombyxmori L. Sericologia 32: 61-65.

29. Datta LC, Saikia MK, Datlo SK (1996) Nutritional efficiency of two multivoltine breeds of Bombyxmori L. native to Assam. Indian Journal Sericulture 35: 32-34

30. Chandrashekharaiah, Ramesh Babu M (2003) Silkworm breeding in India during the last five decades and what next?. Proceedings of the MulberrySilkworm Breeders Summit: 6-13

31. Ding $\mathrm{N}$, Zhang XM, Jiang MQ, Xu WH, Wang ZE, Xu MK (1992)Genetical studies on the dietary efficiency of the silkworm, Bombyxmori L. CanyeKexue 18: 71-76.

32. Gokulamma K, Reddy YS (2005) Role of nutrition and environment on the consumption, growth and utilization indices of selected silkworm races of Bombyxmori L. Indian Journal of Sericulture 44: 165-170.

33. Hassanein MH, El Shaaraway MF, El Garthy AT (1972) Food assimilation and output of the silk in the different races of the silkworm, Bombyxmori L. Bulletin of the Entomological Society of Egypt 56: 333-337.

34. Junliang X, Xiaofeng W(1992) Research on improvement of efficiency of transferring leaf ingested into silk of the silkworm, Bombyxmori $\mathrm{L}$. Abstract.International Congress on Entomology: 623.

35. PrabhakarMK, Reddy DNR, Narayanaswamy KC(2000) Consumption and utilization of mulberry leaves by the silkworm, Bombyxmori L. Bulletin of Indian Academy Sericulture 4: 52-60.

36. Rajesh D, Haemanand A(2005)Nutrigenomics - A future-omics. Advanced Biotech 4: 26-31. 